\title{
Survival of Teliospores of Tilletia indica in Soil
}

M. Babadoost, Department of Crop Sciences, University of Illinois, Urbana 61801; D. E. Mathre and R. H. Johnston, Department of Plant Sciences and Plant Pathology, Montana State University, Bozeman 59717; and M. R. Bonde, United States Department of Agriculture-Agriculture Research Service, Foreign Disease and Weed Science Research Unit, Fort Detrick, MD 21702

\begin{abstract}
Babadoost, M., Mathre, D. E., Johnston, R. H., and Bonde, M. R. 2004. Survival of teliospores of Tilletia indica in soil. Plant Dis. 88:56-62.

This study was conducted to assess survival of Tilletia indica teliospores in a location in the northern United States. Soils differing in texture and other characteristics were collected from four locations, equilibrated to $-0.3 \mathrm{MPa}$, and infested with teliospores of $T$. indica to give a density of $10^{3}$ teliospores per gram of dry soil. Samples $(22 \mathrm{~g})$ of the infested soil were placed in 20- $\mu \mathrm{m}$ mesh polyester bags, which were sealed and placed at 2-, 10-, and 25-cm depths in polyvinyl chloride tubes containing the same field soil as the infested bags. Tubes were buried vertically in the ground at Bozeman, MT, in October 1997. Soil samples were assayed for recovery and germination of $T$. indica teliospores 1 day and 8, 20, and 32 months after incorporation of teliospores into soil. The rates of teliospores recovered from soil samples were 90.2 , 18.7, 16.1, and $13.3 \%$ after 1 day and 8, 20, and 32 months after incorporation of teliospores into soil, respectively, and was significantly $(P<0.01)$ affected by soil source. The percentage of teliospore recovery from soil was the greatest in loam soil and lowest from a silt loam soil. The rate of teliospores recovered from soil was not significantly affected by depth of burial and the soil source-depth interaction during the 32-month period. The percentage of germination of teliospores was significantly $(P<0.01)$ affected by soil source and depth of burial over the $32-$ month period. The mean percentage of teliospore germination at 1 day, and 8, 20, and 32 months after incorporation into soils was $51.3,15.1,16.4$, and $16.5 \%$, respectively. In another experiment, samples of silty clay loam soil with $5 \times 10^{3}$ teliospores of $T$. indica per gram of soil were stored at different temperatures in the laboratory. After 37 months of incubation at 22, 4, -5 , and $-18^{\circ} \mathrm{C}$, the rates of teliospore recovered from soil were $1.6,2.0,5.7$, and $11.3 \%$, respectively. The percentage of spore germination from soil samples was highest at $-5^{\circ} \mathrm{C}$. Microscopy studies revealed that disintegration of teliospores begin after breakdown of the sheath-covering teliospore. The results of this study showed that teliospores of $T$. indica can survive in Montana for more than 32 months and remain viable.
\end{abstract}

Additional keywords: Neovossia indica, Triticum aestivum

Tilletia indica Mitra (= Neovossia indica (Mitra) Mundkur) is the causal agent of Karnal bunt or partial bunt of wheat (Triticum aestivum L.) (14). The disease was reported initially from India in 1931 (14) and since has been recorded in Afghanistan, Iran, Iraq, Mexico, Nepal, and Pakistan (5,20). In 1996, Karnal bunt was found in the United States for the first time (21).

\section{Corresponding author: M. Babadoost}

E-mail: babadoos@uiuc.edu

This research was supported in part by funds from the USDA-ARS, agreements 58-5348-6-841 and 5348-21430-001-055, and Department of Agriculture and Agrifood of Canada contract 01586-7$5383 / 001$.

* The $\boldsymbol{e}$-Xtra logo stands for "electronic extra" and indicates that two figures appear in color online.

Accepted for publication 11 September 2003.

Publication no. D-2003-1113-01R

(C) 2004 The American Phytopathological Society
Teliospores of $T$. indica are introduced into the soil at harvest $(3,18)$ and may persist there for 45 months $(12,20)$. Teliospores on the soil surface germinate and produce primary and secondary sporidia which, under conducive environmental conditions, infect plants at flowering $(3,18,20)$. In India, $T$. indica teliospores survived for 3 years on the surface in field soil, but spores buried $20 \mathrm{~cm}$ deep decreased to low viability after 2 years $(4,6)$. In another investigation in India (12), survival of $T$. indica teliospores on the soil surface and at depths of 7.5 and $15 \mathrm{~cm}$ was reported to be 45,39 , and 27 months, respectively. It was reported that viability of the teliospores decreased with increasing burial depth from 5 to $20 \mathrm{~cm}$ $(15,17) . \quad T$. indica teliospores survived better in loamy sand soil than in clay and sandy loam soil (15). Teliospores survived longer in dry soil than in wet soil $(18,19)$. In laboratory storage, teliospores retained their viability for 5 to 7 years $(10,13,22)$.

The objective of this study was to assess survival of $T$. indica teliospores in a northern U.S. location. A preliminary report of this study has been published (2).

\section{MATERIALS AND METHODS}

Survival of teliospores in the field. Four soils, collected from wheat fields in Montana and Washington (Table 1), were air dried at $22^{\circ} \mathrm{C}$, passed through a $2-\mathrm{mm}$ sieve, and infested with teliospores of $T$. indica (collected in Sonora, Mexico, in 1996) to give a density of $10^{3}$ teliospores per gram of dry soil. Moisture content of all soils was equilibrated to $-0.3 \mathrm{MPa}$ by adding distilled water. Moisture retentions were determined by use of a pressure membrane subjected to $48 \mathrm{~h}$ of pressurized $\mathrm{N}_{2}$ gas (11).

Samples of 22-g of the infested soil were placed in bags constructed from 20$\mu \mathrm{m}$ polyester-mesh (Spectrum Laboratories, Inc., Rancho Domingues, CA) and the bags were completely sealed with hot melt glue. For each soil, three bags containing infested soil were placed within a polyvinyl chloride (PVC) tube $(50 \mathrm{~cm}$ long by 5 $\mathrm{cm}$ in diameter) at depths of 2, 10, and 25 $\mathrm{cm}$, as the tube was filled with the same soil in bags without any T. indica teliospores (noninfested soil). Caps made of PVC couplings, covered with one layer of $20-\mu \mathrm{m}$ polyester mesh and one layer of aluminum window screening mesh, were glued firmly on both ends of the tubes. The caps allowed moisture from rain or melting snow to penetrate soil in the tube. For each soil source, nine PVC tubes were prepared. The tubes were placed vertically in holes dug on a 1-m grid in a secured area on the

Table 1. Soil type, collection locations, and physical characteristics of four soils used to study survival of Tilletia indica teliospores

\begin{tabular}{llccccc}
\hline Soil type & \multicolumn{1}{c}{ Location } & $\mathbf{p H}$ & $\begin{array}{c}\text { Organic } \\
\text { matter }(\boldsymbol{\%})\end{array}$ & $\begin{array}{c}\text { Sand } \\
(\boldsymbol{\%})\end{array}$ & $\begin{array}{c}\text { Silt } \\
(\boldsymbol{\%})\end{array}$ & $\begin{array}{c}\text { Clay } \\
(\boldsymbol{\%})\end{array}$ \\
\hline Silty clay loam & Bozeman, MT & 8.1 & 1.77 & 9 & 59 & 32 \\
Loam & Havre, MT & 7.7 & 1.33 & 40 & 33 & 27 \\
Silt loam & Kalispell, MT & 7.4 & 6.05 & 26 & 51 & 23 \\
Silty clay loam & Pullman, WA & 6.4 & 2.28 & 9 & 63 & 28 \\
\hline
\end{tabular}


Montana State University (MSU) campus at Bozeman (latitude $46^{\circ}$ ) on 21 October 1997, under a U.S. Department of Agriculture Animal and Plant Health and Inspection Service (USDA-APHIS) permit. The experimental design was a randomized complete block split plot with three replications. Soil source was considered the main plot, depth as subplots, and time as a repeated measure. Temperature was monitored hourly, with thermocouples placed 1 $\mathrm{m}$ above the ground, at the soil surface, and within a soil-filled PVC tube at 2, 10, and $25 \mathrm{~cm}$, from 1 November 1997 through 30 June 2000. In addition to the field trial, identically prepared tubes (three tubes per soil source) were maintained at $22^{\circ} \mathrm{C}$ in the Karnal bunt laboratory at MSU.

Initial (time 0) data on recovery and germination of teliospores placed in soils were collected before placing soil in mesh bags, using the procedures developed by Babadoost and Mathre (1). In June 1998, 1999, and 2000, three replicate tubes of each soil source and the tubes stored at room temperature in the laboratory were assayed for recovery and germination of $T$. indica teliospores. Soil samples were air dried at room temperature for 2 days before 10 -g samples were processed for teliospore extraction (1). The extracted teliospores were tested for germination on $2 \%$ water agar (1). Also, a sample of teliospores used to infest soils (original teliospores) was kept at room temperature in the laboratory. Teliospores of this sample were tested for germination on $2 \%$ water agar (1). The percentage of viable telio- spores was calculated as percentage of recovered teliospores that germinated and produced sporidia.

Incorporation or extraction of teliospores in soil, as well as teliospore germination tests, were conducted in the containment facilities of the USDAAgricultural Research Service (ARS), Foreign Diseases and Weeds Science Research Unit (FDWSRU) at Fort Detrick, MD.

Effects of temperature on survival of teliospores in soil. The silty clay loam soil collected from Bozeman, MT, was used to study survival of $T$. indica teliospores at different temperatures over a period of 37 months. Soil was dried at $22^{\circ} \mathrm{C}$, passed through a $2-\mathrm{mm}$ sieve, and infested with teliospores of $T$. indica to give a density of $5 \times 10^{3}$ teliospores per gram of soil. Soil moisture was adjusted to $-0.3 \mathrm{MPa}$ and placed in 50-ml centrifuge tubes (polypropylene, Fisher brand; Fisher Scientific, Pittsburgh, PA). The tubes were capped tightly and wrapped in black plastic. Four centrifuge tubes with infested soil for each temperature-time treatment (a total of 16 treatments) were incubated at room temperature $\left(22^{\circ} \mathrm{C}\right)$ and in three incubators adjusted to $4,-5$, and $-18^{\circ} \mathrm{C}$. Initial data on recovery and germination of teliospores were collected (1) before placing infested soil in tubes in May 1998. In June 1998, 1999, 2000, and 2001, soil samples from each of the 16 centrifuge tubes were dried at room temperature and $10 \mathrm{~g}$ of dry soil was assayed for the presence of $T$. indica teliospores. The extracted teliospores were tested for germination on $2 \%$ water agar. Data were analyzed as a split-plot design with incubation temperature designated as main plots and sampling time as subplots, which were situated in time rather than space.

Morphological changes in teliospores structure. $T$. indica teliospores extracted from the soil samples were examined for morphological changes using light and scanning electron microscopy (9). For light microscopy studies, extracted teliospores were compared with the original teliospores after mounting in Shear's solution (8). For scanning electron microscopy studies, the procedures described by Goldstein et al. (7) were followed. Samples of teliospores suspended in water were deposited on a silicon surface and dried in air. The teliospores then were sputter-coated in a plasma-magnetron sputter unit (Hummer VII; Anatech Ltd., Springfield, VA) with $20 \mathrm{~nm}$ of $\mathrm{Au} / \mathrm{Pd}$. The samples then were placed in the scanning electron microscope (JEOL 6100-JSM; JEOL USA Inc., Peabody, MA) and evacuated to a pressure of approximately $10^{-6}$ Torr. Imaging was accomplished at $10 \mathrm{KV}$, at a working distance of $8 \mathrm{~mm}$.

\section{RESULTS}

Environmental conditions. The site of the Karnal bunt study on the MSU campus was covered with snow from the middle of November through the middle of April each year (Fig. 1). In winter, the snow cover resulted in higher temperatures in soil than in the air. In summer, the mean

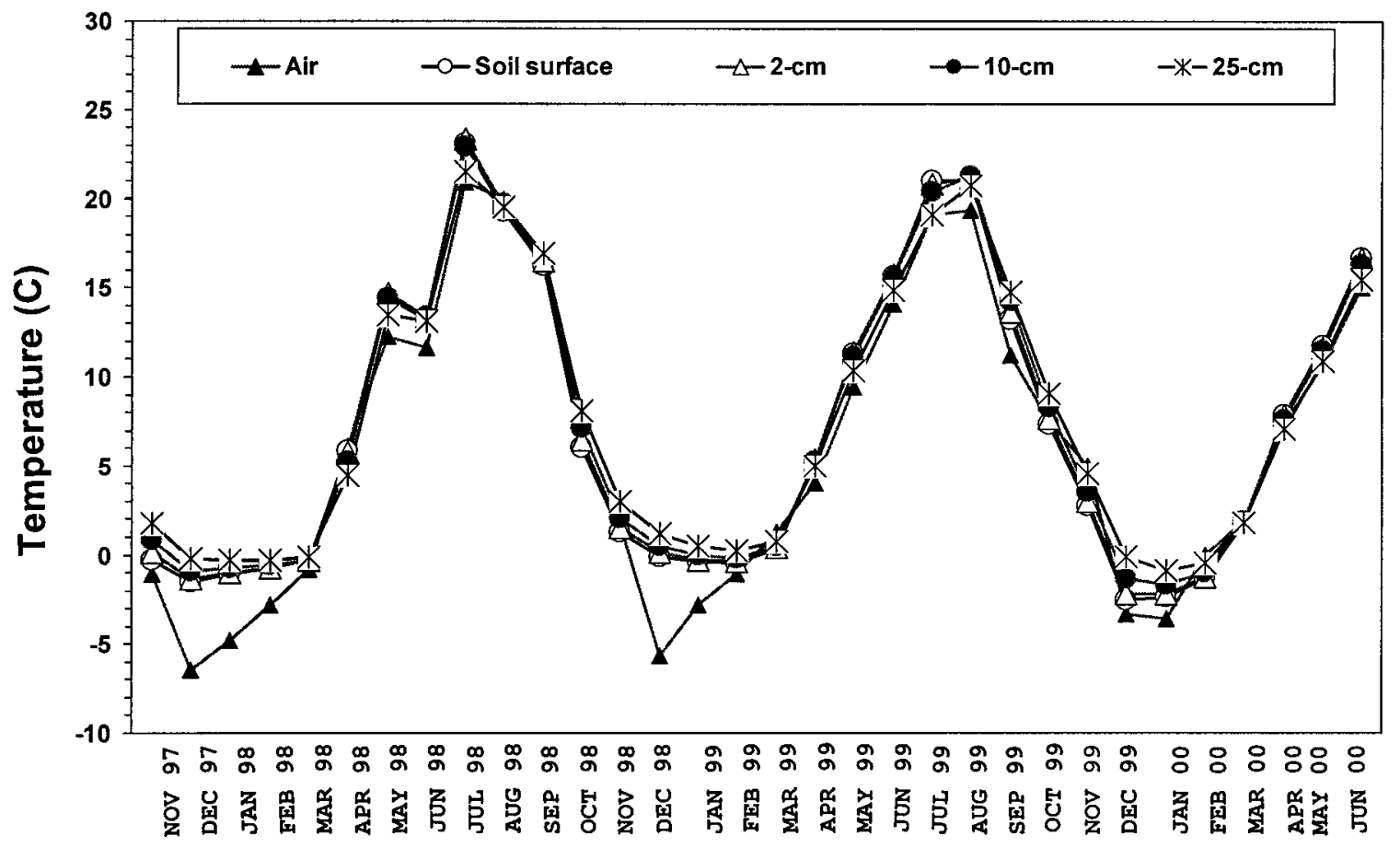

Time (month)

Fig. 1. Monthly mean temperatures $\left({ }^{\circ} \mathrm{C}\right)$ in the air and soil at the Karnal bunt research site at Montana State University campus. Air $=1 \mathrm{~m}$ above the ground; surface, $2-\mathrm{cm}, 10-\mathrm{cm}$, and $25-\mathrm{cm}=$ burial depth in the ground. 
temperature in soil was lower than the mean temperature of the air. Variation in temperature was greatest in air and least at the $25-\mathrm{cm}$ depth. Number of freezing days decreased as depth of soil increased.

Recovery and viability of teliospores in the field. At 32 months after incorporation of teliospores into the soils, $T$. indica teliospores were recovered from all four soil types and all three burial depths and from the soil samples maintained in the laboratory. Soil samples maintained in the laboratory dried out after a few months and teliospore recovery from these soils during 1998 to 2000 did not change significantly (data not presented). The percentage of teliospores recovered from soil samples in the field declined over time (Table 2). Teliospore recovery from soil samples in the field was significantly affected by soil source $(P=0.0001)$ and time period $(P=$ $0.001)$ but not by placement depth. The percentage of teliospores recovered in June 1998 (8 months after incorporation of teliospores into soil) was significantly lower than that of October 1997 (1 day after incorporation of teliospores into soil). Likewise, the percentage of teliospores recovered in June 2000 (32 months after incorporation) was significantly lower than that of June 1998 (8 months after incorporation). The percentage of teliospores recovered from loam soil (Havre) was significantly higher than those of soils from the other three sources (Table 2). In contrast, the percentage of teliospores recovered from silt loam soil (Kalispell) was significantly lower than those of soils from the other three sources. All interactions were nonsignificant for teliospore recovery.
Germination of teliospores was significantly affected by soil source, burial depth, and time over 32 months (Table 2; Fig. 2). With the exception of depth-time (nonsignificant), all interactions were significant $(P=0.0001)$ for teliospore germination. The percentage of germination of teliospores maintained under dry, room-temperature conditions in the containment facility (original teliospores) was significantly higher than the percentage germination of teliospores recovered from soil samples in the field (Table 2). Soil texture had no significant effect on the percentage of germination of teliospores 8 months after incorporation (Table 2). However, 32 months after incorporation, percent germination of teliospores recovered from silty clay loam soil (Pullman) was significantly lower than percent germination of teliospores from soils from the other three sources. Similarly, percent germination of teliospores recovered from loam soil (Havre) was significantly lower than those in silty clay loam soil (Bozeman) and silt loam soil (Kalispell). Depth of burial did not significantly affect teliospore germination 8 months after incorporation of teliospores into soil (Fig. 2). However, 20 and 32 months after incorporation, percent germination of teliospores from soil samples buried $25 \mathrm{~cm}$ deep was significantly higher than those from soil samples buried 2 and $10 \mathrm{~cm}$ deep. The viability of teliospores declined rapidly during 8 months after incorporation of teliospores into soil. The percentages of viable teliospores after 8, 20, and 32 months were significantly lower than that of 1 day after incorporation of teliospores into soil (Table 2). The percentage of viable telio- spores recovered from loam soil (Havre) was significantly higher than those of soils from the other three sources.

Effects of temperature on survival of teliospores. T. indica teliospores survived better at lower temperatures (Table 3). However, teliospores were recovered from the soil samples incubated at all four temperatures for 37 months. Teliospore recovery from soil samples declined significantly over time. Teliospore recovery from soil samples stored at $-18^{\circ} \mathrm{C}$ was significantly higher than those from soil samples incubated at 22 and $4{ }^{\circ} \mathrm{C}$ for time periods greater than 6 weeks. There was no significant difference in teliospore recovery from soil samples incubated at 22 and $4^{\circ} \mathrm{C}$. Likewise, teliospore recovery from soil samples at -5 and $-18^{\circ} \mathrm{C}$ was not significantly different.

Original teliospores germinated at higher frequency than those recovered from soil samples. The percentage of germination of teliospores extracted from soil samples at $-5^{\circ} \mathrm{C}$ was significantly higher than those of teliospores maintained at 22 and $-18^{\circ} \mathrm{C}$ for 6 weeks or longer after incorporation of teliospores into soil. Also, the percentage of germination of teliospores from soil samples maintained at $-5^{\circ} \mathrm{C}$ was significantly higher than those from soil samples maintained at $4^{\circ} \mathrm{C}$, for 25 months or longer after incorporation of teliospores into soil. None of the teliospores extracted from soil samples maintained at $-18^{\circ} \mathrm{C}$ for 37 months germinated. The viability of teliospores declined significantly over the 37-month period. The percentage of viable teliospores recovered from soil samples incu-

Table 2. Recovery and germination of Tilletia indica teliospores from four soil samples buried in the field in Montana from 1997 to 2000

\begin{tabular}{|c|c|c|c|c|c|}
\hline \multirow[b]{2}{*}{ Soil texture } & \multicolumn{4}{|c|}{ Time $^{v}$} & \multirow[b]{2}{*}{ Mean } \\
\hline & 1 day & 8 months & 20 months & 32 months & \\
\hline \multicolumn{6}{|l|}{ Teliospore recovery $(\%)^{\mathrm{w}}$} \\
\hline Silty clay loam (Bozeman) & $94.8 \mathrm{a}$ & $19.0 \mathrm{~b}$ & $13.9 \mathrm{~b}$ & $12.5 \mathrm{~b}$ & $35.1 \mathrm{~b}$ \\
\hline Loam (Havre) & $96.6 \mathrm{a}$ & $27.3 \mathrm{a}$ & $27.2 \mathrm{a}$ & $20.1 \mathrm{a}$ & $42.8 \mathrm{a}$ \\
\hline Silt loam (Kalispell) & $78.6 \mathrm{a}$ & $12.8 \mathrm{c}$ & $10.2 \mathrm{~b}$ & $6.5 \mathrm{c}$ & $27.0 \mathrm{c}$ \\
\hline Silty clay loam (Pullman) & $91.1 \mathrm{a}$ & $15.7 \mathrm{c}$ & $13.0 \mathrm{~b}$ & $14.2 \mathrm{~b}$ & $33.5 \mathrm{~b}$ \\
\hline Mean & $90.2(\mathrm{~A})$ & $18.7(\mathrm{~B})$ & $16.1(\mathrm{BC})$ & $13.3(\mathrm{C})$ & 34.6 \\
\hline \multicolumn{6}{|l|}{ Teliospore germination $(\%)^{\mathrm{w}}$} \\
\hline Original teliospores $^{\mathrm{x}}$ & $49.0 \mathrm{~b}$ & $40.0 \mathrm{a}$ & $39.0 \mathrm{a}$ & $36.7 \mathrm{a}$ & $41.2 \mathrm{a}$ \\
\hline Silty clay loam (Bozeman) & $49.7 \mathrm{~b}$ & $16.3 \mathrm{~b}$ & $15.9 \mathrm{bc}$ & $20.0 \mathrm{~b}$ & $25.5 \mathrm{~b}$ \\
\hline Loam (Havre) & $57.0 \mathrm{a}$ & $15.5 \mathrm{~b}$ & $16.1 \mathrm{bc}$ & $15.4 \mathrm{c}$ & $26.0 \mathrm{~b}$ \\
\hline Silt loam (Kalispell) & $51.0 \mathrm{~b}$ & $14.9 \mathrm{~b}$ & $18.8 \mathrm{~b}$ & $19.7 \mathrm{~b}$ & $26.1 \mathrm{~b}$ \\
\hline Silty clay loam (Pullman) & $47.3 \mathrm{~b}$ & $13.7 \mathrm{~b}$ & $15.0 \mathrm{c}$ & $10.8 \mathrm{~d}$ & $21.7 \mathrm{c}$ \\
\hline Meany & $51.3(\mathrm{~A})$ & $15.1(\mathrm{~B})$ & $16.5(\mathrm{~B})$ & $16.5(\mathrm{~B})$ & 24.9 \\
\hline \multicolumn{6}{|l|}{ Teliospore viability $(\%)^{\mathrm{z}}$} \\
\hline Silty clay loam (Bozeman) & $47.1 \mathrm{~b}$ & $3.0 \mathrm{~b}$ & $2.2 \mathrm{~b}$ & $2.4 \mathrm{ab}$ & $13.7 \mathrm{a}$ \\
\hline Loam (Havre) & $55.1 \mathrm{a}$ & $4.3 \mathrm{a}$ & $4.4 \mathrm{a}$ & $3.2 \mathrm{a}$ & $16.7 \mathrm{a}$ \\
\hline Silt loam (Kalispell) & $40.0 \mathrm{~b}$ & $1.9 \mathrm{~b}$ & $1.9 \mathrm{~b}$ & $1.2 \mathrm{c}$ & $11.3 \mathrm{a}$ \\
\hline Silty clay loam (Pullman) & $43.1 \mathrm{~b}$ & $2.1 \mathrm{~b}$ & $2.0 \mathrm{~b}$ & $1.6 \mathrm{bc}$ & $12.2 \mathrm{a}$ \\
\hline Mean & $46.4(\mathrm{~A})$ & $2.8(\mathrm{~B})$ & $2.6(\mathrm{~B})$ & $2.1(\mathrm{~B})$ & 13.5 \\
\hline
\end{tabular}

${ }^{\mathrm{v}}$ Each value represents the mean of 27 spore counts from three processed soil samples. Time: 1 day $=$ October 1997,8 months $=$ June 1998,20 months $=$ June 1999, and 32 months = June 2000. In each column, values with a letter in common are not significantly different according to Fischer's protected least significant difference (LSD) $(P=0.05)$. Values with a letter in common inside parentheses are not significantly different according to Fischer's protected LSD $(P=0.05)$.

${ }^{w}$ In October 1997, 1,000 teliospores per gram were incorporated into each soil. Teliospores were extracted from 10-g soil samples.

${ }^{x}$ Percentage germination of teliospores stored at $22^{\circ} \mathrm{C}$.

y Mean percentage germination of teliospores extracted from soil samples only.

${ }^{\mathrm{z}}$ Percent viable teliospores $=$ percent of recovered teliospores germinated and produced sporidia. 
bated at $-5^{\circ} \mathrm{C}$ was significantly higher than those of soil samples maintained at 22,4 , and $-18^{\circ} \mathrm{C}$.

Disintegration of teliospores in soil. A sheath covered the body and projections of the $T$. indica teliospore. The sheath became turgid when a teliospore was placed in liquid and appeared as a smooth brown wall (Fig. 3A). Under dry conditions, the sheath stuck to the teliospore projections and was not visible (Fig. 3B, C, and D). Teliospore projections were conical in intact teliospores (Fig. 3B and C). Damaged sheathes lost their turgidity and gradually became separated from the teliospore body (Fig. 4A). The projections on a teliospore that had lost its sheath became separated from each other and lost their conical feature (Fig. 4B, C, and D). Such teliospores lost their original shape and disintegrated.

\section{DISCUSSION}

Teliospores of $T$. indica survive for 3 years or longer in field soil in India $(4,6,18)$. In Montana, we recovered $13.3 \%$ of $T$. indica teliospores, with 1.2 to

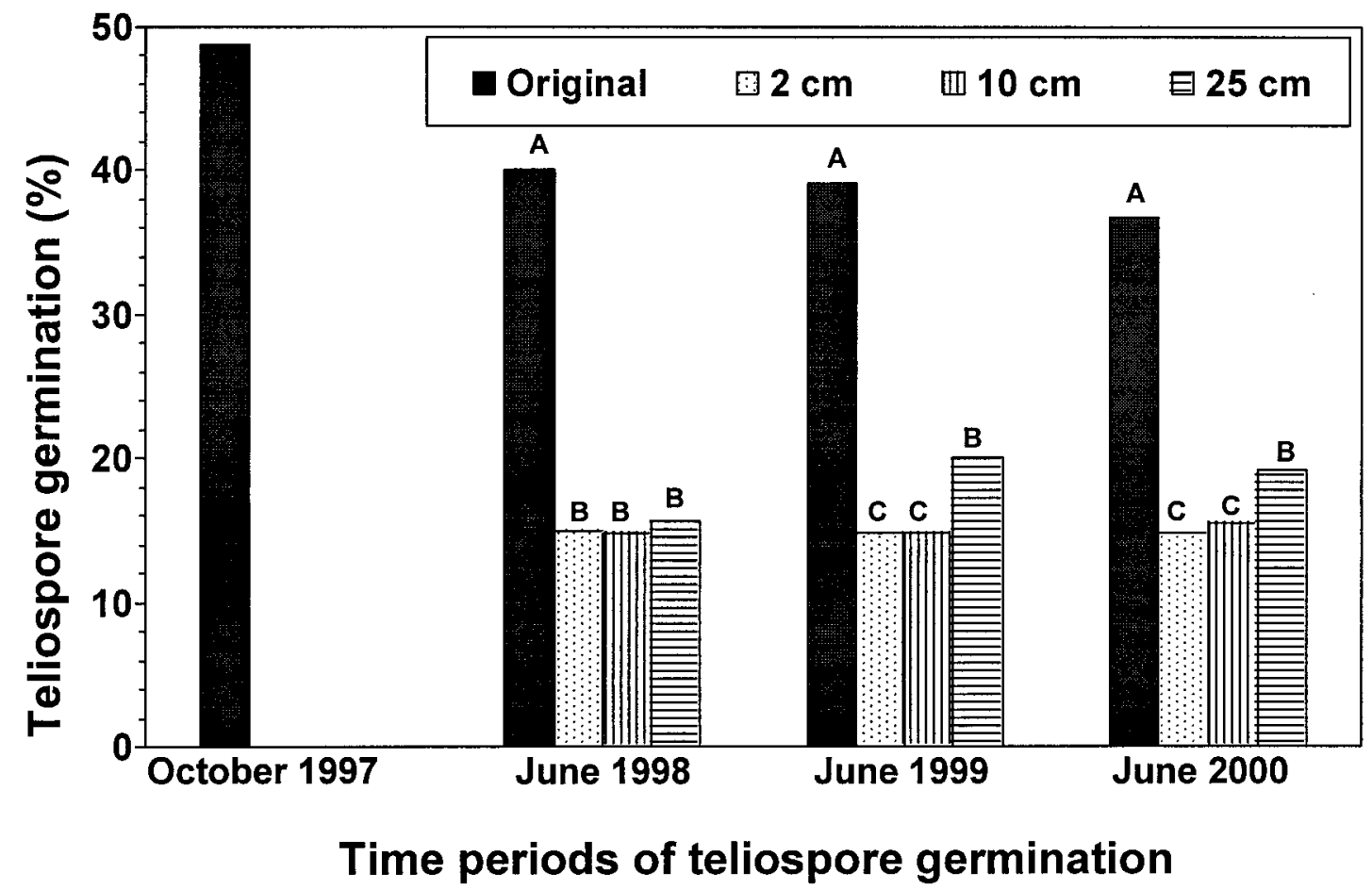

Fig. 2. Percent germination of Tilletia indica teliospores, recovered from soil samples buried 2, 10, and $25 \mathrm{~cm}$ deep in the field in Bozeman, MT, over a 32 -month period. For each date, values with a letter in common are not significantly different according to Fischer's protected least significant difference $(P=0.05)$.

Table 3. Recovery and germination of Tilletia indica teliospores from samples of silty clay loam soil maintained at different temperatures

\begin{tabular}{|c|c|c|c|c|c|}
\hline \multirow[b]{2}{*}{ Temperature $\left({ }^{\circ} \mathbf{C}\right)$} & \multicolumn{5}{|c|}{ Time $^{x}$} \\
\hline & 1 day & 6 weeks & 13 months & 25 months & 37 months \\
\hline \multicolumn{6}{|c|}{ Teliospore recovery $(\%)^{\mathrm{y}}$} \\
\hline Room (22) & 93.8 & $62.4 \mathrm{c}$ & $9.0 \mathrm{~b}$ & $3.7 \mathrm{~b}$ & $1.6 \mathrm{c}$ \\
\hline 4 & $\ldots$ & $67.0 \mathrm{bc}$ & $10.8 \mathrm{~b}$ & $7.3 \mathrm{~b}$ & $2.0 \mathrm{bc}$ \\
\hline-5 & $\ldots$ & $71.0 \mathrm{ab}$ & $28.2 \mathrm{a}$ & $17.1 \mathrm{a}$ & $5.7 \mathrm{ab}$ \\
\hline-18 & $\ldots$ & $76.1 \mathrm{a}$ & $30.1 \mathrm{a}$ & $16.8 \mathrm{a}$ & $11.3 \mathrm{a}$ \\
\hline Mean & 93.8 & $69.1(\mathrm{~A})$ & 19.6 (B) & $11.2(\mathrm{C})$ & $5.2(\mathrm{D})$ \\
\hline \multicolumn{6}{|c|}{ Teliospore germination $(\%)^{\mathrm{y}}$} \\
\hline Room (22) & 43.0 & $12.7 \mathrm{bc}$ & $14.0 \mathrm{~b}$ & $26.3 \mathrm{~b}$ & $9.5 \mathrm{~b}$ \\
\hline 4 & $\ldots$ & $18.2 \mathrm{ab}$ & $24.5 \mathrm{a}$ & $24.5 \mathrm{~b}$ & $11.6 \mathrm{~b}$ \\
\hline-5 & $\ldots$ & $23.8 \mathrm{a}$ & $28.3 \mathrm{a}$ & $31.5 \mathrm{a}$ & $16.5 \mathrm{a}$ \\
\hline-18 & $\ldots$ & $12.0 \mathrm{c}$ & $16.0 \mathrm{~b}$ & $9.5 \mathrm{c}$ & $0.0 \mathrm{c}$ \\
\hline Mean & 43.0 & 16.7 (B) & $20.7(\mathrm{AB})$ & $23.0(\mathrm{~A})$ & $9.4(\mathrm{C})$ \\
\hline \multicolumn{6}{|c|}{ Teliospore viability $(\%)^{\mathrm{y}, \mathrm{z}}$} \\
\hline Room (22) & 43.0 & $8.1 \mathrm{~b}$ & $1.3 \mathrm{c}$ & $1.0 \mathrm{~b}$ & $0.2 \mathrm{~b}$ \\
\hline 4 & $\ldots$ & $12.4 \mathrm{ab}$ & $2.8 \mathrm{bc}$ & $1.8 \mathrm{~b}$ & $0.3 \mathrm{~b}$ \\
\hline-5 & $\ldots$ & $16.9 \mathrm{a}$ & $8.0 \mathrm{a}$ & $5.4 \mathrm{a}$ & $1.0 \mathrm{a}$ \\
\hline-18 & $\ldots$ & $9.0 \mathrm{~b}$ & $4.7 \mathrm{~b}$ & $1.5 \mathrm{~b}$ & $0.0 \mathrm{~b}$ \\
\hline Mean & 43.0 & $11.6(\mathrm{~A})$ & $4.2(\mathrm{~B})$ & $2.4(\mathrm{C})$ & 0.3 (D) \\
\hline
\end{tabular}

${ }^{\mathrm{x}}$ Each value represents the mean of nine spore counts from three processed soil samples. Time: 1 day $=$ May 1998, 6 weeks $=$ June 1998, 13 months $=$ June 1999, 25 months = June 2000, and 37 months = June 2001. In each column, values with a letter in common are not significantly different according to Fischer's protected least significant difference (LSD) $(P=0.05)$. Values with a letter in common inside parentheses are not significantly different according to Fischer's protected LSD $(P=0.05)$.

y In May 1998, 5,000 teliospores per gram were incorporated into soil.

${ }^{\mathrm{z}}$ Percent viable teliospores $=$ percent of recovered teliospores germinated and produced sporidia. 

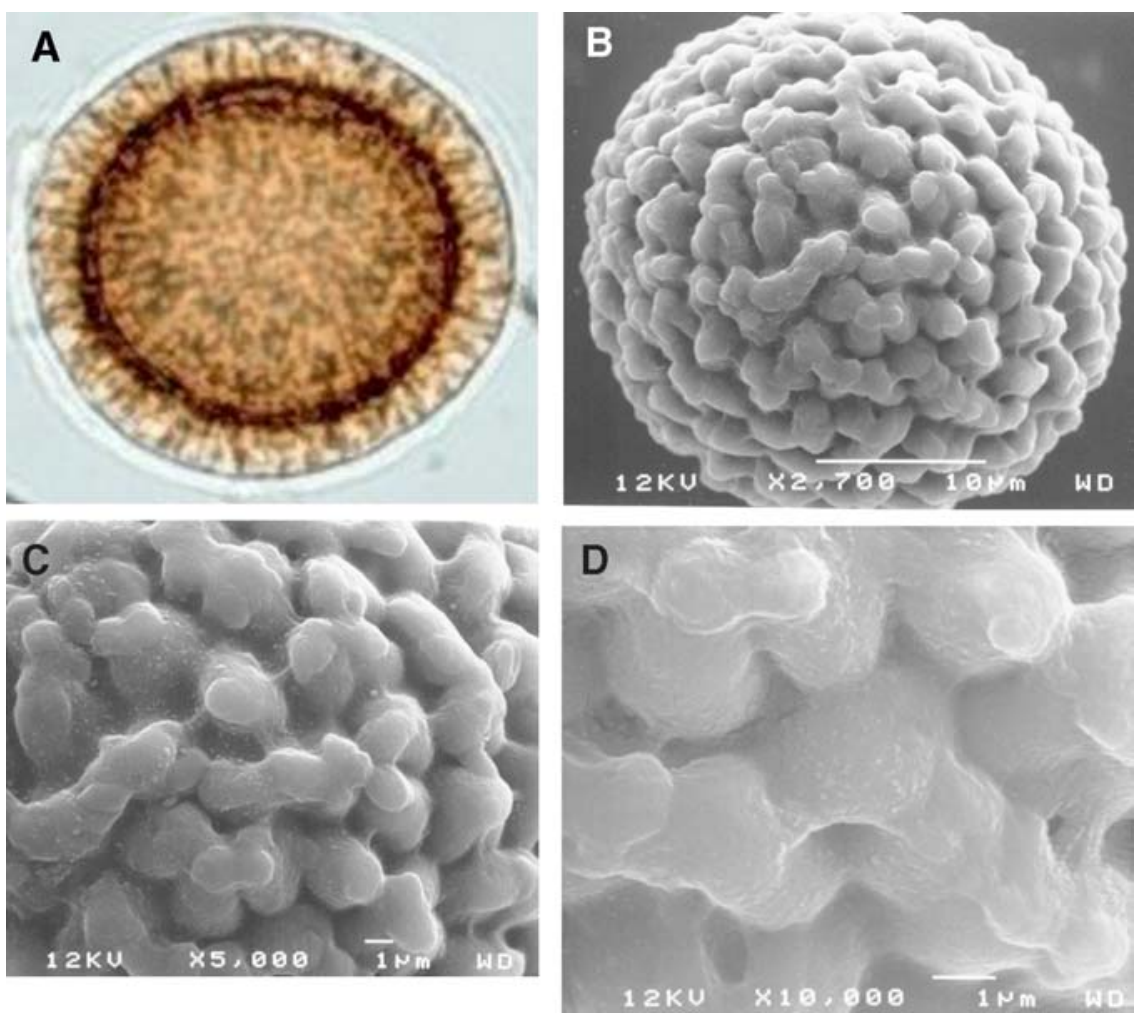

Fig. 3. Body and the sheath morphology of an intact teliospore of Tilletia indica: $\mathbf{A}$, under a compound microscope $(\times 1,000)$ and $\mathbf{B}, \mathbf{C}$, and $\mathbf{D}$, shape and projections of a teliospore viewed by a scanning electron microscope.
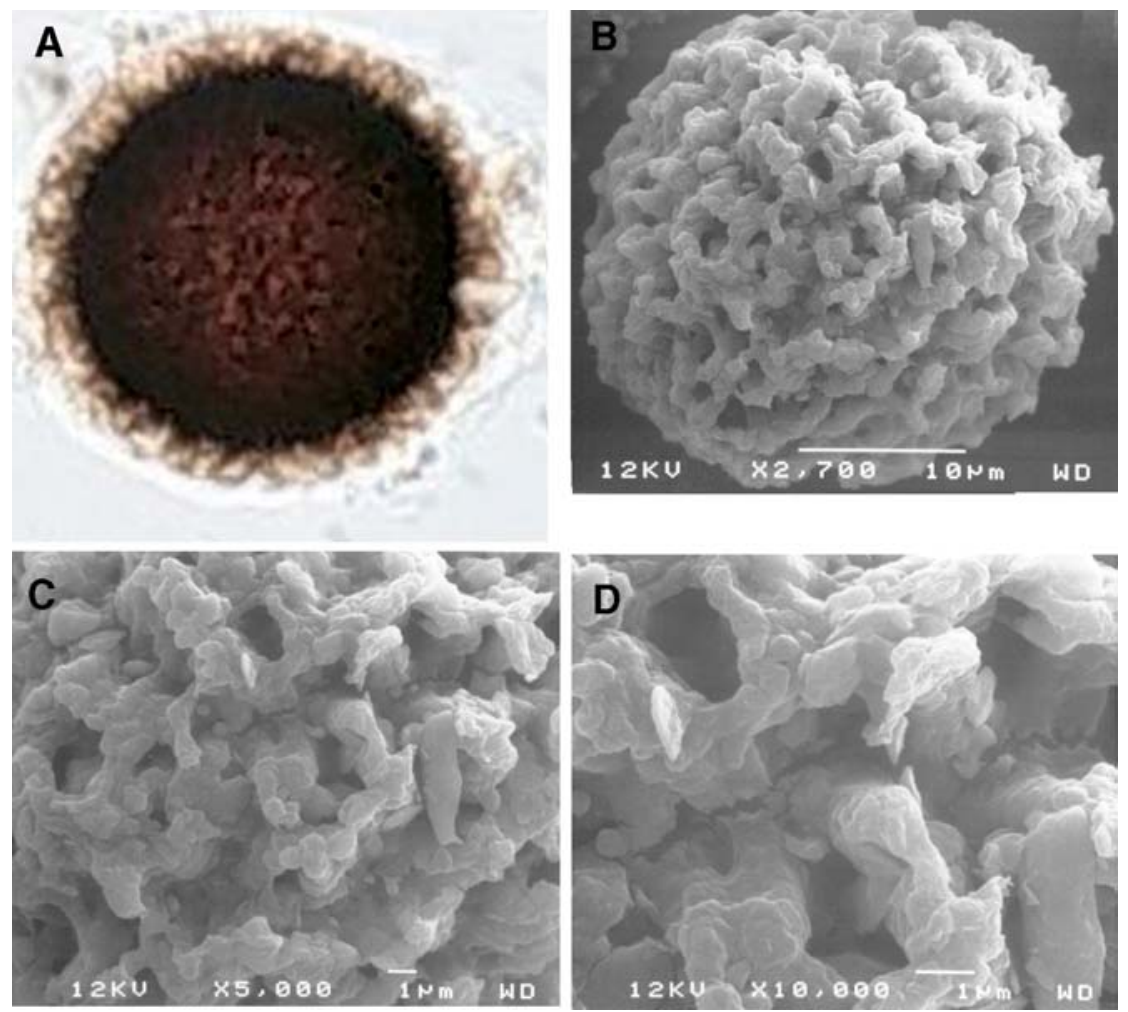

Fig. 4. Body and the sheath of a disintegrating teliospore of Tilletia indica: $\mathbf{A}$, under a compound microscope $(\times 1,000)$ and $\mathbf{B}, \mathbf{C}$, and $\mathbf{D}$, shape and projections of a disintegrating teliospore viewed by a scanning electron microscope. 
$3.2 \%$ (mean $2.1 \%$ ) viability, 32 months after placing infested soil samples in the field. Our results agree with those reported from India and suggest that $T$. indica teliospores could survive for several years.

Studies using light and scanning electron microscopy revealed that disintegration of T. indica teliospores begins after breakdown of the teliospore sheath. The results of field and laboratory experiments showed that more than $70 \%$ of the teliospores in soil were lost during the first year after placing the teliospores in soil. The reduction in teliospore recovery from soil during the second and third years was less than $10 \%$ per year. These results suggest that most of the $T$. indica teliospores may not have had a persistent spore sheath and disintegrated quickly after being placed in a moist soil. Teliospores with a strong sheath remained morphologically intact for a longer period of time and may survive in the soil for more than 3 years.

Rattan and Aujla (15) reported better survival of $T$. indica teliospores in loamy sand soil than in clay and sandy loam soils in India. In their studies, teliospore recovery from soil was the highest for loam soil, intermediate for silty clay soil, and the lowest for silt loam soil. In general, the results of our study agree with their report (15). We recovered a significantly higher percentage of teliospores from loam soil (Havre) than silty clay loam soil (Bozeman and Pullman) and silt loam soil (Kalispell). However, the percentage of germination of teliospores recovered from loam soil was similar to those of teliospores recovered from other soil types. These results suggest that, in order to have conclusive results on the effects of soil types on survival of $T$. indica teliospores, further investigation is needed, and several soils from each soil texture should be included in the study. The silt loam soil collected from Kalispell had the highest organic matter content among the soil types tested in this study, and percentage of teliospore recovery from this soil was the lowest. The percentage of germination of teliospores recovered from this soil, however, was the highest. Thus, further investigation is needed to determine the role of the organic matter in both recovery and survival of $T$. indica teliospores in soil.

Krishna and Singh (12) reported that $T$. indica teliospores survived longer on the soil surface than in soil, and teliospore survival decreased as soil depth increased. They mentioned that no teliospores survived after 27 months at a depth of $15 \mathrm{~cm}$ in Pantnagar, India. In our study, teliospores of $T$. indica survived for more than 32 months at all three depths (2, 10, and 25 $\mathrm{cm})$ in Montana. There was no significant effect of soil depth on teliospore recovery from soil. In addition, after 20 months, germination of teliospores recovered from soil samples buried at $25 \mathrm{~cm}$ was significantly higher than those of soil samples buried at 2 and $10 \mathrm{~cm}$. The differences between the report by Krishna and Singh (12) and the results from our study may be related to the effects of soil moisture and temperature on survival of teliospores, as reported by Rattan and Aujla (16). When we stored infested soil samples with $T$. indica teliospores in the Karnal bunt laboratory in Bozeman, teliospore recovery decreased as long as the soil samples were wet. Temperatures at depths of 2 and $10 \mathrm{~cm}$ were higher than those at 25 $\mathrm{cm}$ during summer. However, there were no significant changes in teliospore recovery or germination after the soil samples dried in less than 8 months. Also, in our laboratory experiment, the percentage of teliospores recovered from soil samples stored at room temperature was significantly lower than those from soil samples maintained at -5 and $-18^{\circ} \mathrm{C}$ for 13 months or longer.

Sidharta et al. (17) reported that freezing for 10 days or longer induced cold dormancy in $T$. indica teliospores for at least 10 days. In our studies, teliospore germination was determined 10 to 14 days after plating the teliospores on $2 \%$ water agar. We found that the percentage of germination of teliospores extracted from soil samples maintained at $-18^{\circ} \mathrm{C}$ was significantly lower than those of teliospores from soil samples at 4 and $-5^{\circ} \mathrm{C}$. In contrast, the percentage of germination of teliospores incubated at $-5^{\circ} \mathrm{C}$ was significantly higher than that of teliospores from soil samples at $22^{\circ} \mathrm{C}$. The results of our studies indicated that deep freezing (e.g., $-18^{\circ} \mathrm{C}$ ) might delay germination of some teliospores. However, freezing in general does not appear to have a significant effect on germination of $T$. indica teliospores. The results of our results may underestimate the germinability of teliospores because some of the old and weathered teliospores might have been killed during surface sterilization by sodium hypochlorite. We suggest further testing to determine the importance of cold temperatures, and contact with snow, on germination of $T$. indica teliospores.

This study was carried out to evaluate survival of $T$. indica teliospores under Montana conditions. The results of the field study showed that $T$. indica teliospores survived over 32 months in all soil types and at all depths tested. The results of the laboratory study revealed that the percentage of teliospore survival at lower temperatures was greater than that of teliospore survival in higher temperatures. However, survival of $T$. indica teliospores in soil in Montana neither proves nor rejects the possibility of Karnal bunt development in Montana or any other areas in the Great Plains and Pacific Northwest. We were not allowed to work with live teliospores of $T$. indica in wheat fields in Mon- tana because of quarantine concerns; therefore, we could not study Karnal bunt disease development under field conditions.

\section{ACKNOWLEDGMENTS}

We thank S. Nester at USDA-ARSFDWSRU for providing teliospores of $T$. indica and arranging for the testing of materials at the containment facilities at Fort Detrick, MD; and J. Martin in the Department of Plant Sciences and Plant Pathology, Montana State University, for his assistance in statistical analysis of the data.

\section{LITERATURE CITED}

1. Babadoost, M., and Mathre, D. E. 1998. A method for extraction and enumeration of teliospores of Tilletia indica, T. controversa, and T. barclyana in soil. Plant Dis. 82:13571361.

2. Babadoost, M., and Mathre, D. E. 1999. Survival of Tilletia indica teliospores in Montana. (Abstr.) Phytopathology 89:S4.

3. Bonde, M. R., Peterson, G. L., Schaad, N. W., and Smilanick, J. L. 1997. Karnal bunt of wheat. Plant Dis. 81:1370-1377.

4. Chib, M. S., Kalha, C. S., Gupta, B. R., Tikar, M. L., and Gupta, R. S. 1990. Studies on the longevity of Neovossia indica - the incitant of Karnal bunt of wheat, in soil. Plant Dis. Res. 5:17-18.

5. Fuentes-Davila, G. 1997. Karnal bunt of wheat. Pages 69-81 in: Bunts and Smuts of Wheat: An International Symposium. V. S. Malik and D. E. Mathre, eds. North American Plant Protection Organization, Ottawa, Canada.

6. Gill, K. S., Sharma, I., and Aujla, S. S. 1993. Karnal Bunt and Wheat Production. Punjab Agricultural University Publishing, Ludhiana, India.

7. Goldstein, J. T., Romig, A. D., Jr., Newbury, D. E., Lyman, C. E., Echlin, P., Fiori, C., Joy, D. C., and Lifshin, E. 1992. Coading and conductivity techniques for SEM and microanalysis, Plasma-Magnetron Sputtering. Pages 705706 in: Scanning Electron Microscopy and XRay Microanalysis: A Text for Biologists, Material Scientists, and Geologists. Plenum Press, New York.

8. Graham, S. O. 1959. The effects of various reagents, mounting media, and dyes on the teliospore wall of Tilletia controversa Kühn. Mycologia 51:477-491.

9. Hess, W. M., and Gardner, J. S. 1988. Spore wall structure of Karnal bunt teliospores. Pages 55-67 in: Experimental and Conceptual Plant Pathology. Vol. 1. R. S. Singh, U. S. Singh, W. M. Hess, and D. J. Weber, eds Gorden and Breach Science Publishers, New York

10. Kiryukhina, R. I., and Scherbakova, L. I 1976. On the viability of the pathogen of Indian smut of wheat. (Abstr.) Zashch. Rast. 7:50.

11. Klute, A. 1986. Water retention: laboratory methods. Pages 635-662 in: Methods of Soil Analysis, Physical and Mineralogical Methods, Part 1, 2nd ed. A. Klute, ed. The American Society of Agronomy, Madison, WI.

12. Krishna, A., and Singh, R. A. 1983. Longevity of teliospores of Neovossia indica causing Karnal bunt of wheat. Indian J. Mycol. Plant Pathol. 13:97-98.

13. Mathur, S. C., and Ram, S. 1963. Longevity of Chlamydospores of Neovossia indica (Mitra) Mundkur. Sci. Cult. 29:411-412.

14. Mitra, M. 1931. A new bunt of wheat in India Ann. Appl. Biol. 18:178-179.

15. Rattan, G. S., and Aujla, S. S. 1990. Survival of Karnal bunt (Neovossia indica) teliospores 
in different types of soil at different depths. Indian J. Agric. Sci. 60:616-618.

16. Rattan, G. S., and Aujla, S. S. 1992. Ecology of germination of teliospores of Karnal bunt pathogen (Neovossia indica). Indian J. Agric. Sci. 62:228-231.

17. Sidharta, V. S., Singh, D. V., Srivastava, K. D., and Aggarwal, R. 1995. Some epidemiological aspects of Karnal bunt of wheat. Indian Phytopathol. 48:419-426.

18. Singh, A. 1994. Epidemiology and manage- ment of Karnal bunt disease of wheat. Res. Bull. No. 127, Directorate of Experiment Station, G. B. Pant University of Agriculture and Technology, Pantnagar, India.

19. Smilanick, J. L., Prescott, J. M., Hoffman, J. A., Secrest, L. R., and Weise, K. 1989. Environmental effects on survival and growth of secondary sporidia and teliospores of Tilletia indica. Crop Prot. 8:86-90.

20. Warham, E. J. 1986. Karnal bunt disease on wheat: literature survey. Trop. Pest Manag.
32:229-242.

21. Ykema, R. E., Floyd, J. P., Palm, M. E., and Peterson, G. L. 1996. First report of Karnal bunt of wheat in the United States. Plant Dis. 80:1207.

22. Zhang, Z., Lange, L., and Mathur, S. B. 1984 Teliospore survival and plant quarantine significance of Tilletia indica (causal agent of Karnal bunt)-particularly in relation to China. Eur. Plant Prot. Organ. Bull. 14:119 128. 